https://doi.org/10.5800/GT-2017-8-3-0263

\title{
PETROGRAPHY AND MINERALOGY OF RETROGRADE METAPERIDOTITES FROM ALAG KHADNY ACCRETIONARY WEDGE (SW MONGOLIA): FLUID MODIFICATION IN SUPRASUBDUCTION ZONE
}

\author{
M. A. Gornova1, D. Enkhbat ${ }^{2}$, A. A. Karimov' 1 , \\ V. A. Belyaevi, ${ }^{1}$, 0. Gerel ${ }^{4}$, O. Javkhlan ${ }^{4}$ \\ ${ }^{1}$ A.P. Vinogradov Institute of Geochemistry, Siberian Branch of RAS, Irkutsk, Russia \\ ${ }^{2}$ Institute of Paleontology and Geology, Mongolian Academy of Sciences, Ulaanbaatar, Mongolia \\ ${ }^{3}$ Institute of Earth Sciences, Academia Sinica, Taipei, Taiwan \\ ${ }^{4}$ Mongolian University of Science and Technology, Ulaanbaatar, Mongolia
}

The Main Mongolian Lineament (MML) separates northern "Caledonian" tectonic province from southern "Hercynian" in SW part of Mongolia of the Central Asian Orogenic Belt (CAOB). The position of Eastern part of MML is widely discussed at recent time, since, this is an important for reconstruction of geodynamic evolution of this region. Some researchers suggest that ophiolite from the Erdene Uul and Maykhan Tsakhir Uul mountain ranges are Eastern part of an ophiolitic nappe system thrust northwards over the Dzabkhan-Baydrag continent, namely the Khantaishir and the Dariv ophiolites [Štípská et al., 2010; Buriánek et al., 2017]. Others have a different view, they suggest that investigated ophiolites refers to Gobi-Altai ophiolite system (523 \pm 5
- 518 $\pm 6 \mathrm{Ma}$ ), which likely formed in front of the Gobi Altai microcontinent by initiation of a new southdipping subduction zone following arc-microcontinent collision in Northwest Mongolia [Jian et al., 2014]. However, ophiolites of this critical region of Mongolian the CAOB have not been investigated in detail.

Geological setting and petrography. The studied metaperidotites are situated in the area of the Maykhan Tsakhir Uul mountain range. After recent mapping by Czech geologists, the serpentinies were included into the Alag Khadny crystalline complex interpreted as an accretionary wedge [Hanžl, Aichler, 2007]. The Alag Khadny crystalline complex overlies Neoproterozoic crystalline basement rocks of the Zamtyn Nuruu Crys- 
talline Complex. The Alag Khadny accretionary wedge forms $10 \mathrm{~km}$ long and up to $4 \mathrm{~km}$ wide $\mathrm{E}-\mathrm{W}$ oriented belt. The northern part of the belt is built of orthogneiss bodies alternating with layers of mica schists and paragneisses. Retrogressed eclogites, marbles and serpentinites form lenses and boudins enclosed in mica schists and orthogneisses. The southern part of the belt contains large body of serpentinized peridotite rimmed by lenticular bodies of ophicarbonates. The matrix of the mélange is fragment of Neoproterozoic to Early Cambrian carbonate platform scrapped off the subducting plate during the mid-Cambrian accretion [Buriánek et al., 2017]. The eclogites geochemically correspond to T-MORB modified by fluid circulation and were metamorphosed at peak pressure-temperature (PT) conditions of 20-22.5 kbar and $590-610{ }^{\circ} \mathrm{C}$ [Štípská et al., 2010]. The subduction event is dated at ca. $538 \pm 20 \mathrm{Ma}$ on zircon from orthogneisses [Buriánek et al., 2017].

The serpentinized peridotites are dominantly massive. Samples with LOI less than 9 wt. \% show a diagnostic mineral assemblage of olivine + orthopyroxene + + tremolite + chlorite + spinel. Olivine (Ol1) grains are large and cut by serpentine veinlets. 012 is formed after Ol1 in veinlets. The rocks contain both large (up to 7 $\mathrm{mm}$ ) and small (up to $300 \mu \mathrm{m}$ ) pseudomorphs after orthopyroxene, composed of tremolite + olivine $3+$ clinopyroxene $2+$ serpentine $\pm \mathrm{Cr}$-magnetite. In the centers of pseudomorphs there are relics of orthopyroxene with clinpyroxene lamellae. Olivine 3 from pseudomorphs forms small crystals $20-60 \mu \mathrm{m}$ in size. There are three generations of clinopyroxene. $\mathrm{Cpx} 1$ composes irregular grains up to first hundred $\mu \mathrm{m}$ in size; it is located close to former orthopyroxene and does not have orthopyroxene lamellae. Cpx2 represents fine needlelike crystals in association with tremolite, formed after orthopyroxene. Cpx3 is irregular-shaped, up to $0.5 \mathrm{~mm}$ in size, and contains small olivine grains (up to $20 \mu \mathrm{m}$ ) and spinel; lamellae of orthopyroxene lack. Cpx3 develops after olivine and orthopyroxene pseudomorphs, as well as in cracks within olivine. Spinel grains are rounded and irregular, size is rather small with rare grains reaching 500-600 $\mu \mathrm{m}$. Homogeneous central parts of grains are surrounded by thin ferrite-chromite rims, rim's thikness is wider in more serpentinized rocks. Chlorite occurs as coronas around metamorphosed chromian spinel. Flakes of chlorite are sometimes associated with tremolite and serpentine. Tremolite occurs as fine needle-like crystals after orthopyroxene and as prismatic crystals between olivine grains. Serpentine occurs either as needles or blades after both orthopyroxene and tremolite or as flame-like interpenetrating laths after olivine.

The rocks are tremolite-chlorite peridotites formed mainly after harzburgite with a porphyroclastic texture.

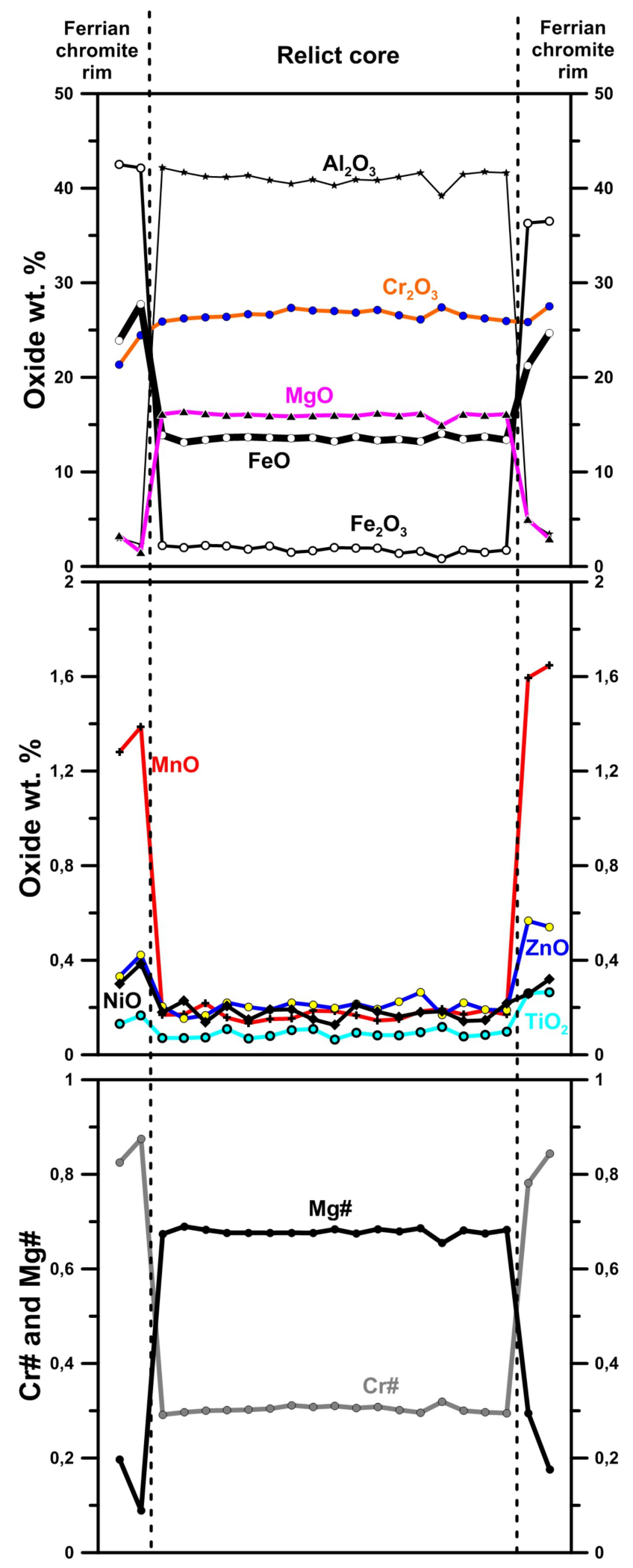

Fig. 1. Microanalysis profiles across spinel in Alag Khadny metaperidotites.

Bulk-rock and mineral chemistry. Loss on ignition varies 5 to 13 wt. \% in the rocks. Oxide contents varies: $\mathrm{SiO}_{2} 44$ to 46 wt. \%., $\mathrm{MgO} 43$ to $47 \%, \mathrm{Al}_{2} \mathrm{O}_{3} 0.65$ to 1.6 wt. \%, $\mathrm{CaO} 0.26$ to 3.01 wt. \%, $\mathrm{FeO} 6$ to 7.7 wt. \%, $\mathrm{TiO}_{2} 0.01$ to 0.06 wt. $\%$. $\mathrm{Na}_{2} \mathrm{O}$ and $\mathrm{K}_{2} \mathrm{O}$ abundances 


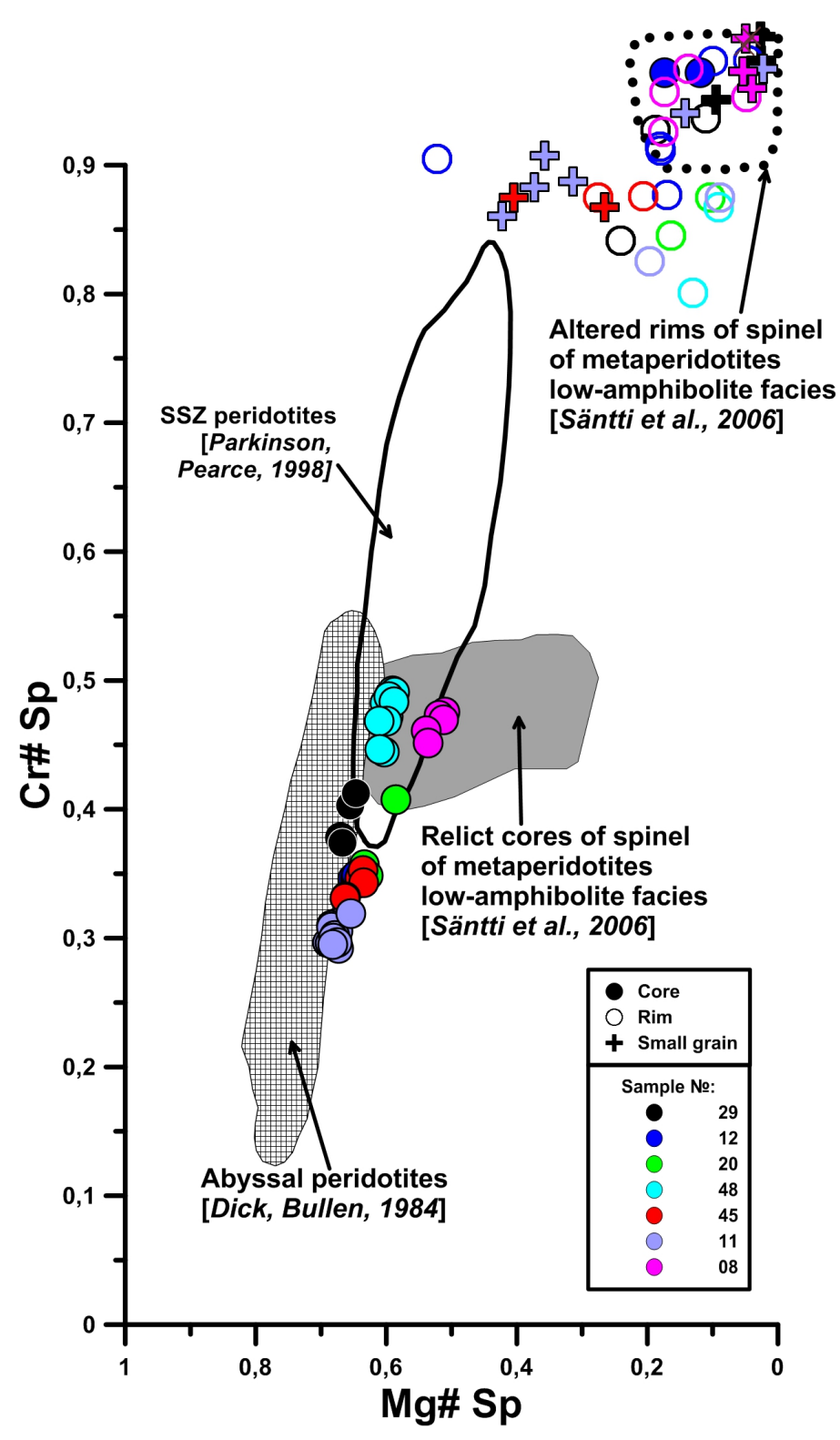

Fig. 2. $\mathrm{Cr} /(\mathrm{Cr}+\mathrm{Al})$ vs. $\mathrm{Mg} /\left(\mathrm{Mg}+\mathrm{Fe}^{2+}\right)$ of spinel from Alag Khadny metaperidotites.

are below 0.1 and 0.01 wt. \%, respectively. In the Alag Khadny metaperidotites $\mathrm{MgO}$ exceeds and $\mathrm{Al}_{2} \mathrm{O}_{3}, \mathrm{CaO}$, $\mathrm{TiO}_{2}, \mathrm{Na}_{2} \mathrm{O}$ and $\mathrm{K}_{2} \mathrm{O}$ are below primitive mantle abundances. The rocks show decrease in $\mathrm{Al}_{2} \mathrm{O}_{3}, \mathrm{CaO}, \mathrm{TiO}_{2}$ with increase in $\mathrm{MgO}$, as would be expected in residues after varying melting degree. At the same time, $\mathrm{CaO}-$ $\mathrm{Al}_{2} \mathrm{O}_{3}$ positive correlation lacks, and samples with similar $\mathrm{Al}_{2} \mathrm{O}_{3}$ contents show large scatter in $\mathrm{CaO}$. This indicates apparent gain of $\mathrm{CaO}$ during metamorphism. Based on $\mathrm{MgO}, \mathrm{Al}_{2} \mathrm{O}_{3}$ and $\mathrm{TiO}_{2}$ abundances, the protoliths of the Alag Khadny metaperidotites were harzburgites with intermediate depletion degree.

Central parts of spinel grains are homogeneous (Fig. 1) with $\mathrm{Cr} \#$ 0.3-0.5, $\mathrm{Mg} \# 0.65-0.50$ and low $\mathrm{Fe}_{2} \mathrm{O}_{3}$ (1.6-4.6 wt. \%), $\mathrm{TiO}_{2}$ (<0.1 wt. \%), $\mathrm{MnO}$ ( $<0.3$ wt. \%) and $\mathrm{ZnO}(<0.4$ wt. \%). Such composition is common for primary spinels of mantle residual peridotites. On $\mathrm{Mg \#}$ - Cr\# plot (Fig. 2), the studied spinels correspond to abyssal peridotites. The ferrite-chromite rims are more Cr\# (0.80-0.99) with lower $\mathrm{Mg \#}(<0.3), \mathrm{Al}_{2} \mathrm{O}_{3}, \mathrm{MgO}$, and higher $\mathrm{Fe}_{2} \mathrm{O}_{3}$ (38-42 wt. \%) and $\mathrm{MnO}$ (1-2 wt. \%). During prograde metamorphism of peridotites in the greenschist facies, their spinels attain $\mathrm{FeO}, \mathrm{MnO}, \mathrm{ZnO}$ zoning due to release of these oxides from olivine and pyroxenes serpentinization. In the epidote-amphibolite facies, ferrite-chromite forms around the zonal spinel core because of $\mathrm{Al}_{2} \mathrm{O}_{3}, \mathrm{MgO}$ loss and $\mathrm{FeO}, \mathrm{Fe}_{2} \mathrm{O}_{3}$ gain. In the Alag Khadny metaperidotites the spinel cores are not zoned and thus ferrite-chromite rims formation is not related to prograde regional epidote-facies metamorphism, but is caused by the retrograde metamorphic event.

Olivine 1 has $\mathrm{MgO}(0.90-0.92)$ and $\mathrm{NiO}(0.31-0.45)$ abundances similar to residual mantle olivines testifying their primary nature (Fig. 3). Olivine 2 and olivine 3 contain $0.81-0.87$ and $0.85-0.89$ wt. \% MgO, 0.02-0.44 and $0.33-0.48$ wt. \% NiO, respectively, and have a metamorphic genesis. In the $\mathrm{Mg \# Ol} \mathrm{-} \mathrm{Cr \# Sp} \mathrm{space} \mathrm{(Fig.} \mathrm{4),}$ compositions of $\mathrm{Ol} 1$ and Al-Cr Sp of the Alan-Hadny metaperidotites are located within the olivine-spinel mantle array and abyssal peridotite field, arguing for residual origin.

Orthopyroxenes are enstatite with high Mg\#s (0.910.92), $\mathrm{Al}_{2} \mathrm{O}_{3}$ and $\mathrm{Cr}_{2} \mathrm{O}_{3}$ contents are 1.7-2.6 wt. \% and 0.33-0.59 wt. \%, respectively. Such compositions are common for orthopyroxenes in alpine-type peridotites. Presence of clinopyroxene lamellae within orthopyroxene also points at magmatic genesis of the orthopyroxene.

Clinopyroxenes of all the three generations are diopsides of similar composition with a narrow range of Mg\#, 0.94-0.97. They have contents of $\mathrm{Al}_{2} \mathrm{O}_{3}$ (1.0-2.4 wt. \%) and $\mathrm{Cr}_{2} \mathrm{O}_{3}$ (0.35-0.77 wt. \%) similar to those in orthopyroxenes and tremolites. Cpx 1 is considered as a retrogressive product of clinopyroxene lamellae in orthopyroxenes. Cpx 2 and $\mathrm{Cpx} 3$ could have formed during metamorphism, and $\mathrm{Cpx} 3$ in course of Ca addition.

Tremolites have high Mg\# (0.98), appreciable amounts of $\mathrm{Al}_{2} \mathrm{O}_{3}$ (1.5-2.1 wt. \%), $\mathrm{Na}_{2} \mathrm{O}$ (1.1-2.4 wt. \%) and $\mathrm{Cr}_{2} \mathrm{O}_{3}$ (0.31-0.52). High $\mathrm{Al}_{2} \mathrm{O}_{3}$ and $\mathrm{Cr}_{2} \mathrm{O}_{3}$ are probably derived from precursor orthopyroxene. They are similar to retrograde tremolites in terms of $\mathrm{Na}-\mathrm{Si}$ relationship [Khedr et al., 2010].

P-T conditions of the Alag Khadny peridotite and geodynamic implications. The Alag Khadny peridotite preserved both primary magmatic paragenesis (olivine $1+$ orthopyroxene $+\mathrm{Cr}-\mathrm{Al}$ spinel) and metamorphic associations (chlorite + tremolite + olivine $2+$ + olivine 3 + clinopyroxene $2+$ clinopyroxene $3+$ serpentine + ferrite-chromite rims of spinels). 


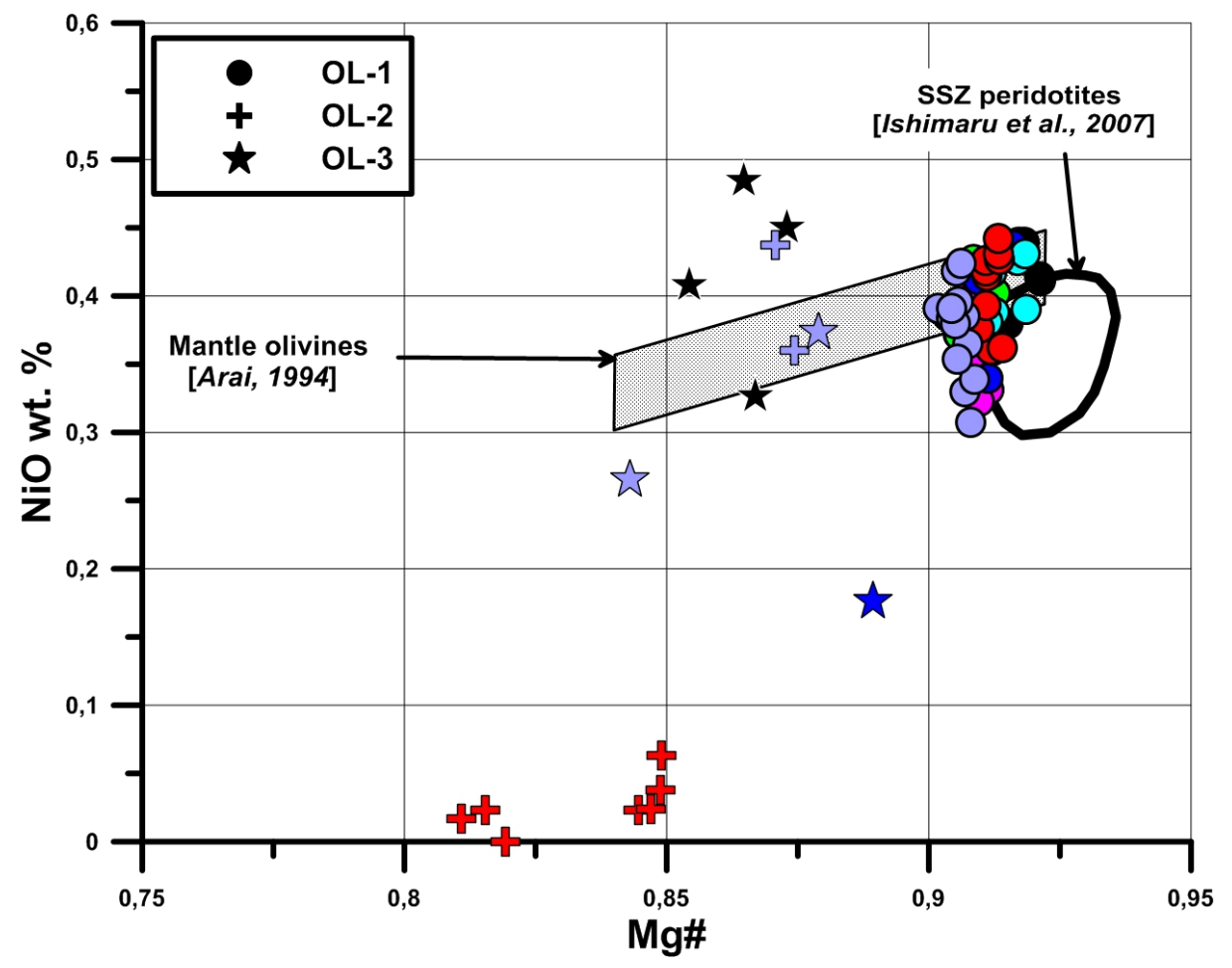

Fig. 3. $\mathrm{Mg} /\left(\mathrm{Mg}+\mathrm{Fe}^{2+}\right)$ vs. $\mathrm{NiO}$ (wt. \%) content for olivine of the Alag Khadny metaperidotites.

According to primary mineral compositions, the Alag Khadny primary harzburgites are residual after 13-23\% of melting of depleted mantle (DM) during basalt formation in mid-ocean ridges, forearc or backarc basins.

Petrographic observations and mineral compositions argue for the retrograde metamorphism of the rocks. Water addition to anhydrous harzburgites could trigger secondary mineral formation as a result of reactions:

$\mathrm{Ol} 1+\mathrm{En}+\mathrm{Sp} \rightarrow \mathrm{Chl}$,

$\mathrm{En}+\mathrm{Di}+\mathrm{H}_{2} \mathrm{O} \rightarrow \mathrm{Tr}+\mathrm{Fo}(\mathrm{Ol} 3)$,

$\mathrm{Tr}+\mathrm{Fo}+\mathrm{H}_{2} \mathrm{O}+\mathrm{Ca} \rightarrow \mathrm{Di}(\mathrm{Cpx} 2, \mathrm{Cpx} 3)+\mathrm{Atg}$.

Association olivine + orthopyroxene + tremolite + chlorite without anthophilite and talc is stable at 640$750{ }^{\circ} \mathrm{C}$ and 16-20 kbar [Khedr et al., 2010, Fig. 12; Padrón-Navarta et al., 2010]. The pressure range corresponds to spinel facies of the mantle, but temperature estimates are lower compared to the ocean geotherm. Lower temperature can be caused by water addition. Middle-temperature $\left(400-700{ }^{\circ} \mathrm{C}\right)$ metamorphism of abyssal peridotites as result downward seawater flow alteration refers to retrograde type. But it happens at lower part of oceanic earth crust $(\mathrm{P}<5 \mathrm{kbar})$ during the mantle rise up and characterized by Ca elution [Bazylev et al., 1990]. The Alag Khadny metaperidotites are associated with eclogites and have P-T conditions of metamorphism similar to the latter. Therefore, it is more probable that Alag Khadny peridotites (olivine $1+$ orthopyroxene $+\mathrm{Cr}-\mathrm{Al}$ spinel) were in mantle wedge above the subduction zone. The subducted metamorphosed oceanic crust experienced dehydration could be the source of water. The water penetrated mantle

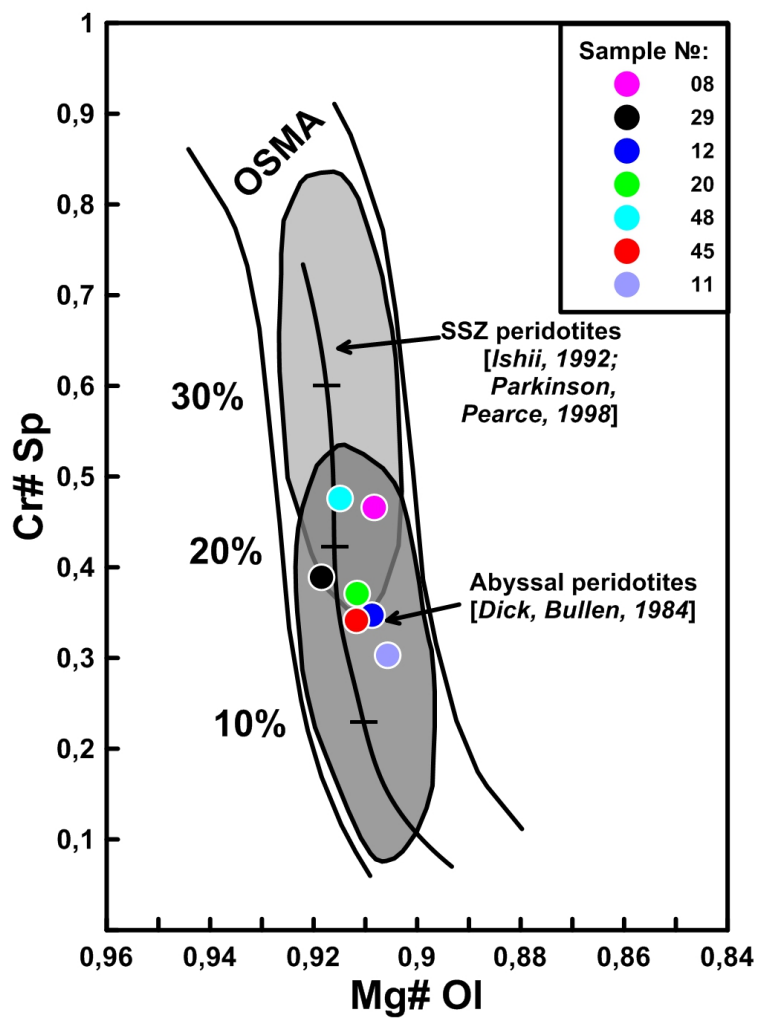

Fig. 4. Olivine-spinel mantle array (OSMA) of the Alag Khadny metaperidotites. 
wedge peridotites leading to formation of metaperidotites containing water-bearing minerals. Finally, the Alag Khadny metaperidotites together with eclogites were exhumed into the crust.
Acknowledgements. The study was supported by the Russian Foundation for Basic Research, Project 1605-44038 Mong_a.

\section{REFERENCES}

Arai S., 1994. Compositional variation of olivine-chromian spinel in Mg-rich magmas as a guide to their residual spinel peridotites. Journal of Volcanology and Geothermal Research 59 (4), 279-293. https://doi.org/10.1016/03770273(94)90083-3.

Bazylev B.A., Silantiev S.A., Kononkova N.N., 1990. Hyperbasite metamorphism at the oceanic crust. In: Yu.M. Pushcharovsky, B.P. Zolotarev (Eds.), Magmatism and tectonics of ocean. Nauka, Moscow, p. 296-318 (in Russian).

Buriánek D., Schulmann K., Hrdličková K., Hanžl P., Janoušek V., Gerdes A., Lexa O., 2017. Geochemical and geochronological constraints on distinct Early-Neoproterozoic and Cambrian accretionary events along southern margin of the Baydrag continent in western Mongolia. Gondwana Research 47, 200-227. https://doi.org/10.1016/j.gr.2016. 09.008

Dick H.J.B, Bullen T., 1984. Chromium-spinel as a petrogenetic indicator in abyssal and alpine-type peridotites and spatially associated lavas. Contributions to Mineral Petrology 86, 54-76. https://doi.org/10.1007/BF00373711.

Hanžl P. Aichler J., 2007. Geological Survey of the Mongolian Altay at a Scale 1:50000 (Zamtyn nuruu - 50). Final Report. Czech Geological Survey, Prague, Czech Republic, 389 p.

Ishii T., 1992. Petrological studies of peridotites from diapiric serpentinite seamounts in the Izu-Ogasawara-Mariana forearc, Leg 125. Proceedings of the Ocean Drilling Program, Scientific Results 125, 445-485. https://doi.org/ 10.2973/odp.proc.sr.125.129.1992.

Ishimaru S., Arai S., Ishida Y., Shirasaka M., Okrugin V.M., 2007. Melting and multi-stage metasomatism in the mantle wedge beneath a frontal arc inferred from highly depleted peridotite xenoliths from the Avacha volcano, southern Kamchatka. Journal of Petrology 48 (2), 395-433. https://doi.org/10.1093/petrology/egl065.

Jian P., Kröner A., Jahn B., Windley B.F., Shi Y., Zhang W., Zhang F., Miao L., Tomurhuu D., Liu D., 2014. Zircon dating of Neoproterozoic and Cambrian ophiolites in West Mongolia and implications for the timing of orogenic processes in the central part of the Central Asian Orogenic Belt. Earth-Science Reviews 133, 62-93. https://doi.org/10.1016/ j.earscirev.2014.02.006.

Khedr M.Z., Arai S., Tamura A., Morishita T., 2010. Clinopyroxenes in high-P metaperidotites from Happo-0'ne, central Japan: implications for wedge-transversal chemical change of slab-derived fluids. Lithos 119 (3), 439-456. https://doi.org/10.1016/j.lithos.2010.07.021.

Padrón-Navarta J.A., Hermann J., Garrido C. J., Sánchez-Vizcaíno V.L., Gómez-Pugnaire M.T., 2010. An experimental investigation of antigorite dehydration in natural silica-enriched serpentinite. Contributions to Mineralogy and Petrology 159 (1), 25-42. https://doi.org/10.1007/s00410-009-0414-5.

Parkinson I.J., Pearce J.A., 1998. Peridotites from the Izu-Bonin-Mariana forearc (ODP Leg 125): evidence for mantle melting and melt-mantle interaction in a supra-subduction zone setting. Journal of Petrology 39 (9), 1577-1618. https://doi.org/10.1093/petroj/39.9.1577.

Säntti J., Kontinen A., Sorjonen-Ward P., Johanson B., Pakkanen L., 2006. Metamorphism and chromite in serpentinized and carbonate-silica-altered peridotites of the Paleoproterozoic Outokumpu-Jormua Ophiolite Belt, Eastern Finland. International Geology Review 48 (6), 494-546. https://doi.org/10.2747/0020-6814.48.6.494.

Štípská P., Schulmann K., Lehmann J., Corsini M., Lexa O., Tomurhuu D., 2010. Early Cambrian eclogites in SW Mongolia: evidence that the Palaeo-Asian ocean suture extends further east than expected. Journal of Metamorphic Geology 28 (9), 915-933. https://doi.org/10.1111/j.1525-1314.2010.00899.x. 